STUDIA I PRACE WYDZIAŁU NAUK EKONOMICZNYCH I ZARZĄDZANIA nr 40, t. 1

\author{
Marzena Matkowska* \\ Uniwersytet Szczeciński
}

\title{
PROCESY MIGRACYJNE W POAKCESYJNEJ POLSCE
}

\section{Streszczenie}

W artykule dokonano identyfikacji najważniejszych zmian w procesach migracyjnych w Polsce po przystąpieniu do Unii Europejskiej w celu udzielenia odpowiedzi na pytanie, na jakim etapie transformacji migracyjnej znajduje się obecnie nasz kraj? Celowi pracy zastała podporządkowana jej struktura. W pierwszej części artykułu scharakteryzowano kierunki emigracji z Polski i jej zmiany na przestrzeni dziesięciu lat, kolejna jego część zawiera analizę statystyczną tendencji w rozmiarach i strukturze imigracji.

Słowa kluczowe: migracje zagraniczne, emigracja z Polski, imigracja do Polski, transformacje migracyjne

\section{Wprowadzenie}

Przystąpienie Polski do Unii Europejskiej w 2004 roku spowodowało wiele zmian instytucjonalnych, ekonomicznych i społecznych. Konsekwencje członkostwa Polski można zaobserwować również w procesach migracyjnych. Mijające dziesięciolecie skłania do dokonania oceny sytuacji migracyjnej w poakcesyjnej Polsce. Większość państw Unii Europejskiej przeszła - w różnym okresie po przystąpieniu do ugrupowania - proces transformacji migracyjnej. W krajach tych

\footnotetext{
*Adres e-mail: marzena@wneiz.pl.
} 
nastąpiło przejście od kraju emigracji netto do kraju imigracji netto. Doświadczenie innych krajów UE daje podstawę do wysunięcia tezy, że Polskę też czeka droga od kraju o ujemnym saldzie migracji, następnie neutralnym, aż do kraju z dodatnim saldem. Ten etap będzie prawdopodobnie stanem docelowym większości krajów europejskich, jakkolwiek czas jego osiągnięcia może być różny dla poszczególnych państw Europy Środkowo-Wschodniej. Tempo przekształceń jest niewątpliwie uzależnione przede wszystkim od sytuacji ekonomicznej tych państw oraz uwarunkowań prawnych.

Celem artykułu jest próba identyfikacji dotychczasowych przekształceń w strumieniach i zasobach polskiej poakcesyjnej migracji, a w efekcie udzielenie odpowiedzi na pytanie, na jakim etapie transformacji migracyjnej znajduje się obecnie nasz kraj? Czy Polska, podobnie jak Irlandia czy Hiszpania, ma szansę na pozbycie się „trwałego stereotypu kraju emigracji”", czy też może realizujemy inny scenariusz przemieszczania się ludności?

\section{Charakterystyka emigracji Polaków po 2004 roku}

Przystąpienie Polski do Unii Europejskie w 2004 roku wywołało istotne zmiany w strumieniach naszej emigracji. Przed tym okresem, praktycznie do końca lat 90. XX wieku, liczba zarejestrowanych wyjazdów Polaków za granicę na pobyt stały była dosyć stabilna, jeśli nie liczyć przemieszczeń ludności tuż po zakończeniu drugiej wojny światowej i dużej emigracji po wydarzeniach z 1956 roku.

Analizując dane dotyczące wielkości polskiej emigracji, należy zaznaczyć, że prowadzenie statystyki dotyczącej emigracji Polaków jest znacznie utrudnione w warunkach swobodnego przepływu osób. Mimo formalnego obowiązku zgłaszania wyjazdu za granicę na pobyt czasowy, tylko niewielka część Polaków wywiązuje się z tego obowiązku. W tej sytuacji Główny Urząd Statystyczny przeprowadza szacunki liczby osób przebywających czasowo za granicą. Podstawą tych szacunków są zarówno źródła krajowe, jak zagraniczne². Dane, które nie mają charakteru

${ }^{1}$ M. Okólski, Polska jako aktor na europejskiej scenie migracyjnej, w: Współczesne migracje, dylematy Europy i Polski, Uniwersytet Warszawski, Ośrodek Badań nad Migracjami, Warszawa 2009, s. 11-13.

${ }^{2}$ Szerzej na ten temat zob. Metoda szacunku liczby osób przebywających czasowo za granica w latach 2002-2008, GUS, Departament Badań Demograficznych, www.stat.gov.pl (dostęp kwiecień 2014). 
szacunkowego, dotyczą tylko osób, które zgłosiły swój wyjazd na pobyt stały (wymeldowały się) lub czasowy (powyżej 3 miesięcy). Ponieważ jednak niewiele osób dopełnia tego obowiązku, dane te nie dają pełnego obrazu polskiej emigracji. W efekcie w artykule wykorzystano różne źródła danych statystycznych.

Otwarcie unijnych rynków pracy wywołało gwałtowny wzrost emigracji z Polski. Potwierdzają to zarówno dane dotyczących strumieni (rysunek 1), jak i zasobów emigrantów (rysunek 2). W 2008 roku liczba emigrantów czasowych wzrosła ponad pięciokrotnie w porównaniu z rokiem 2003. Liczba osób nieobecnych w Polsce w związku z wyjazdem za granicę wzrosła w tym samym czasie prawie trzykrotnie. Po wybuchu kryzysu w gospodarce światowej w polskiej emigracji pojawiła się tendencja spadkowa. Kryzys spowodował spadek liczby miejsc pracy i już w 2008 roku wyraźnie wyhamował napływ pracowników z Polski do USA, Islandii, Irlandii i Wielkiej Brytanii, a potem do wielu innych państw³.

Rysunek 1. Emigracja na pobyt stały i czasowy w wybranych latach 2003-2013 (tys.)

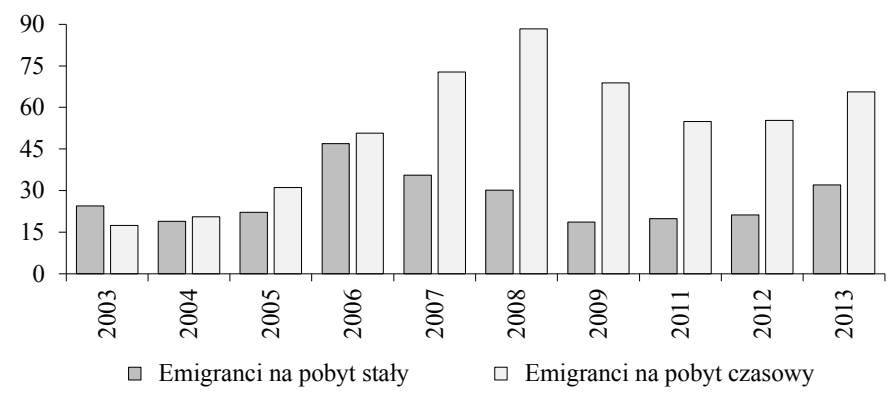

Źródło: opracowanie własne na podstawie Rocznika Demograficznego za poszczególne lata.

Po okresie wyhamowania fali emigracji w kolejnych latach liczba migrantów z Polski znowu zaczęła rosnąć. W 2013 roku za granicą przebywało już prawie 2,2 mln Polaków, a więc prawie tyle samo, co w 2007 roku (rysunek 2). Strumień emigrantów stałych i czasowych również wykazuje wyraźną tendencję wzrostową w latach 2012-2013 (rysunek 1).

\footnotetext{
${ }^{3}$ Informacja $w$ sprawie zatrudnienia obywateli polskich $w$ państwach Europejskiego Obszaru Gospodarczego i Szwajcarii oraz obywateli państw EOG w Polsce, maj 2010, Raport Ministerstwa Pracy i Polityki Społecznej, www.mpips.gov.pl (dostęp luty 2014).
} 
Rysunek 2. Ludność nieobecna w Polsce w związku z wyjazdem za granicę na pobyt czasowy w latach 2002-2013 (tys.)

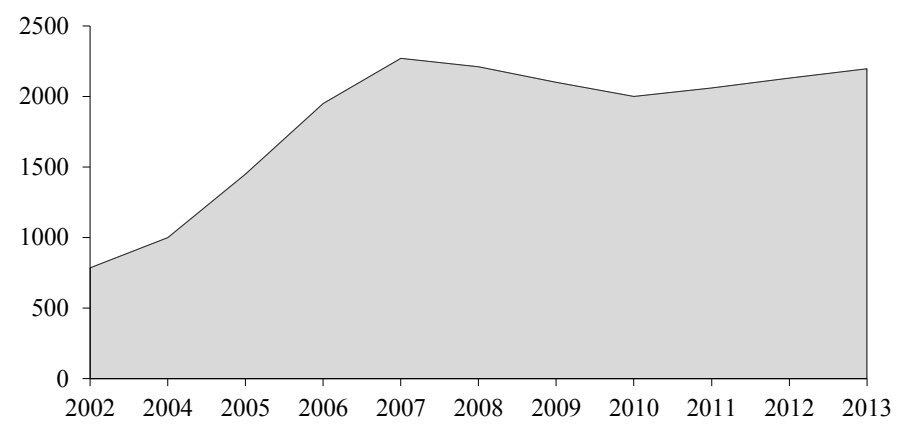

*Dane za 2002 rok pochodzą z Narodowego Spisu Powszechnego 2002.

Źródło: Informacja o rozmiarach kierunkach czasowej emigracji z Polski w latach 2004-2013, Raport GUS, Warszawa 2014, www.stat.gov.pl (dostęp październik 2014).

Po akcesji Polski do UE nastąpiła wyraźna zmiana kierunków emigracji. Nastąpiło przesunięcie punktu ciężkości z Niemiec i USA - dotychczasowych krajów docelowych emigracji Polaków, na Wielką Brytanię oraz Irlandię. Były to kraje, które jako pierwsze otworzyły swoje rynki pracy. Znacznie wzrosła też liczba Polaków przebywających w Holandii, Norwegii i Szwecji (rysunek 3).

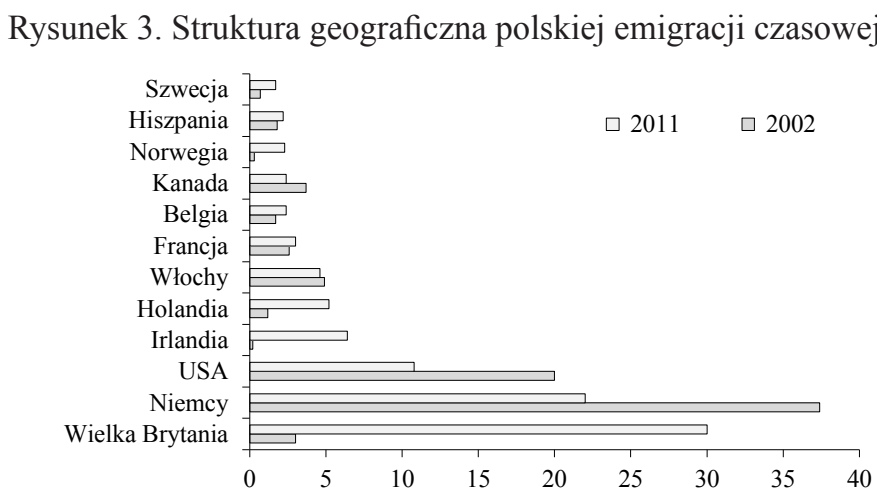

Źródło: obliczenia własne na podstawie Migracje zagraniczne ludności w 2002 roku, www.stat.gov.pl/gus, s. 178 oraz Narodowy Spis Powszechny Ludności i Mieszkań 2011, Warszawa 2013, s. 50-52 (dostęp listopad 2013). 
W 2013 roku najwięcej mieszkańców naszego kraju przebywało w Wielkiej Brytanii, Niemczech, Irlandii oraz Holandii i we Włoszech. Spośród tych państw tylko w Irlandii zmniejszyły się zasoby Polaków w porównaniu z poprzednim rokiem (tabela 1). Spadek odnotowano również w Hiszpanii i Grecji. W krajach tych występuje relatywnie wysokie bezrobocie wywołane kryzysem ekonomicznym.

Tabela 1. Liczba Polaków przebywających za granicą według kraju pobytu (tys.)

\begin{tabular}{|l|c|c|c|c|c|}
\cline { 2 - 6 } \multicolumn{1}{c|}{} & $2002(\mathrm{NSP})$ & 2006 & 2008 & 2010 & 2013 \\
\hline Wielka Brytania & 24 & 580 & 650 & 580 & 642 \\
\hline Niemcy & 294 & 450 & 490 & 440 & 560 \\
\hline Irlandia & 2 & 120 & 180 & 133 & 115 \\
\hline Holandia & 10 & 55 & 108 & 92 & 103 \\
\hline Włochy & 39 & 85 & 88 & 92 & 96 \\
\hline Norwegia &. &. & 38 & 46 & 71 \\
\hline
\end{tabular}

Źródło: jak pod rysunkiem 2.

Kierunki polskiej emigracji zostały zdeterminowane tempem znoszenia ograniczeń w dostępie do rynków pracy krajów UE w pierwszym etapie oraz sytuacją ekonomiczną i poziomem opieki społecznej (Norwegia) w kolejnym etapie naszego członkostwa w UE. Jednak oprócz warunków życia w krajach przyjmujących polskich emigrantów istotną rolę odegrały również takie czynniki, jak: bliskość geograficzna, uwarunkowania historyczne oraz ukształtowane sieci migracyjne 4 .

Szczegółowa analiza zmian, jakie zaszły w charakterystyce społeczno-demograficznej emigracji Polaków, jest możliwa tylko na podstawie danych NSP 2002 i NSP 2011. Najliczniejsze grupy wśród polskich emigrantów czasowych stanowiła ludność w wieku 25-29 lat oraz 30-34 (odpowiednio 19\% i 17\%)5. W tych grupach wiekowych nastąpił największy przyrost w porównaniu z rokiem 2002. Podwoił się odsetek wyjeżdżających dzieci w wieku 0-9 lat (z 4,2\% w 2002 r. do 8\% w 2012 r.) . $^{6}$ Dane te wskazują, że częściej niż kiedyś emigrują całe rodziny z dziećmi.

${ }^{4}$ Informacja o rozmiarach i kierunkach emigracji z Polski w latach 2004-2013...

${ }^{5}$ M. Matkowska, Obraz polskiego emigranta w świetle danych Narodowego Spisu Powszechnego Ludności i Mieszkań 2011, „Studia i Prace Wydziału Nauk Ekonomicznych i Zarządzania” nr 35, t. 1, Wydawnictwo Naukowe Uniwersytetu Szczecińskiego, Szczecin 2014, s. 199.

${ }^{6}$ Ibidem, s. 200. 
W okresie pomiędzy spisami wyraźnie wzrósł wśród emigrantów udział ludzi z wykształceniem wyższym i średnim (prawie dwukrotnie), spadł natomiast z wykształceniem podstawowym (dwukrotnie). Bardzo ciekawe jest porównanie poziomu wykształcenia emigranta z poziomem wykształcenia ogółu Polaków. Z danych NSP 2011 wynika, że polski emigrant jest lepiej wykształcony niż przeciętny Polak, przy czym największe dysproporcje występują w odniesieniu do wykształcenia średniego i wyższego. Można zatem stwierdzić, że polska emigracja poakcesyjna charakteryzowała się selektywnością i nadreprezentatywnością ludzi młodych oraz z wyższym wykształceniem w stosunku do ogółu populacji?

Polski rynek pracy ma strukturalne problemy. Najważniejsze z nich to niedopasowania o charakterze kompetencyjnym i geograficznym. Dlatego w emigrację zaangażowali się przede wszystkim młodzi, dobrze wykształceni mieszkańcy polskich peryferii, z niewielkimi szansami na znalezienie satysfakcjonującej pracy ${ }^{8}$. Można się zatem spodziewać, że brak poprawy sytuacji na polski rynku pracy oraz wysokie bezrobocie będą nadal ważnymi czynnikami wypychającymi ludzi na emigrację i raczej nie będą zachęcać do powrotu do Polski.

\section{Procesy imigracyjne do poakcesyjnej Polski}

Przed 1990 rokiem liczba osób imigrujących do Polski była znikoma. Stan ten wynikał z ówczesnej sytuacji politycznej i gospodarczej w Polsce. Wraz ze zmianą uwarunkowań nastąpił wzrost imigracji do naszego kraju. Według danych Narodowego Spisu Powszechnego Ludności i Mieszkań 2011 na temat obywatelstwa wśród stałych mieszkańców Polski, 55,4 tysiąca osób to cudzoziemcy, czyli osoby nieposiadające polskiego obywatelstwa. W porównaniu z danymi NSP 2002 liczba cudzoziemców osiadłych w Polsce wzrosła prawie o 38\%9. Udział

${ }^{7}$ Zob. J. Brzozowski, P. Kaczmarczyk, Konsekwencje migracji poakcesyjnych z polski dla kompetencji zawodowych $i$ kulturowych polskiego społeczeństwa, Komitet Badań nad Migracjami PAN, Warszawa 2014, s. 16.

${ }^{8}$ P. Kaczmarczyk, Poakcesyjne migracje Polaków - próba bilansu, „Studia Migracyjne - Przegląd Polonijny" 2010, nr 4, Warszawa, s. 5-36.

${ }^{9}$ Obliczenia własne na podstawie Narodowy Spis Powszechny Ludności i Mieszkań 2011. Raport z wyników, www.stat.gov.pl (dostęp lipiec 2014), s. 96. 
cudzoziemców w populacji naszego kraju wzrósł z 0,1\% w 2002 roku do $0,14 \%$ w $2011 \mathrm{roku}^{10}$.

Według Urzędu do Spraw Cudzoziemców, na koniec 2013 roku ważne karty pobytu ${ }^{11}$ posiadało 121 tysięcy cudzoziemców, natomiast 60 tysięcy obywateli UE zarejestrowało swój pobyt w Polsce ${ }^{12}$. Oznacza to, że na koniec 2013 roku udział cudzoziemców (z UE i spoza niej) w liczbie ludności Polski wynosił 0,47\%. Liczba cudzoziemców, którzy uzyskali karty pobytu w Polsce, wykazywała stałą tendencję wzrostową. W latach 2007-2013 średnie roczne tempo wzrostu wynosiło 8\% ${ }^{13}$.

Mimo wzrostu liczby obcokrajowców Polska nadal jest na ostatnim miejscu w UE pod względem udziału cudzoziemców w populacji kraju ${ }^{14}$. Nawet jeżeli uwzględnimy wyższy wskaźnik obliczony na podstawie danych Urzędu do Spraw Cudzoziemców, to nasza sytuacja na tle UE prawie się nie zmienia. Wskaźnik 0,47\% daje nam przedostatnią pozycję, pomiędzy Rumunią $(0,2 \%)$ a Węgrami $(0,5 \%)^{15}$. Podobnie wygląda sytuacja pod względem udziału imigrantów w polskim rynku pracy. Szacunki liczby migrantów zarobkowych w Polsce są bardzo zróżnicowane i w zależności od metodologii pomiaru wskazują na to, że cudzoziemcy stanowią od $0,02 \%-0,07 \%$ siły roboczej ${ }^{16}$. Niezależnie od źródeł danych widać wyraźnie, że cudzoziemcy nadal stanowią niewielki procent 17 milionowego polskiego rynku pracy.

Bardziej szczegółowa analiza zmian tendencji w rozmiarach i strukturze imigracji po naszej akcesji do UE jest możliwa tylko na podstawie danych GUS, stąd też w dalszej części artykułu podstawą analizy będą dane pochodzące z tego źródła. 2014).

${ }^{10}$ Obliczenia własne na podstawie danych NSP 2002 i NSP 2011, www.stat.gov.pl (dostęp lipiec

${ }^{11}$ Karta pobytu poświadcza legalny pobyt cudzoziemca na terytorium Polski, potwierdza tożsamość cudzoziemca - jest to odpowiednik dowodu osobistego.

12 Dane Urzędu do Spraw Cudzoziemców, www.udsc.gov.pl/Zestawieniaroczne (dostęp lipiec 2013).

${ }^{13}$ Karty stałego pobytu wydawane są od 2007 roku. s. 43 .

${ }^{14}$ European Social Statistics. 2013 Edition, http://epp.eurostat.ec.europa.eu (dostęp lipiec 2013),

15 Ibidem.

${ }^{16}$ Zaspokajanie potrzeb polskiego rynku pracy poprzez migracje, Raport krajowy przygotowany przez Europejską Sieć Migracyjną, www.emn.gov.pl (dostęp luty 2012). 
Skala imigracji na pobyt stały była w całym analizowanym okresie niewielka (rysunek 4). Charakterystyczne jest to, że w 2013 roku aż 87\% imigrantów na pobyt stały to obywatele Polski, przy czym prawie $52 \%$ urodziło się w naszym kra$\mathrm{ju}^{17}$. Liczby te wskazują na występowanie zjawiska reemigracji. Cudzoziemcy na pobyt stały to obywatele m.in. Wielkiej Brytanii, Irlandii, Niemiec, Ukrainy, Stanów Zjednoczonych ${ }^{18}$. Nie ma możliwości przeanalizowania zmian, jakie nastąpiły w strukturze obywatelstwa imigrantów na pobyt stały, gdyż GUS nie podawał takich danych dla lat 2004-2008.

Rysunek 4. Liczba imigrantów do Polski na pobyt stały i czasowy w latach 2003-2013 (tys.)

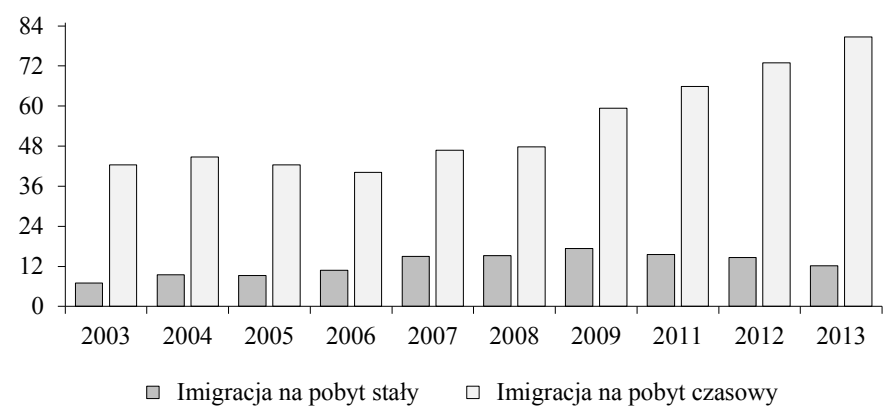

Źródło: opracowanie własne na podstawie roczników demograficznych GUS za odpowiednie lata.

Liczba imigrantów na pobyt czasowy wynosiła w 2013 roku prawie 81 tysięcy, co w porównaniu z 2003 rokiem oznaczało prawie dwukrotny wzrost (rysunek 4). Kryzys gospodarczy nie zahamował napływu cudzoziemców do Polski. Liczba imigrantów czasowych rosła prawie w całym analizowanym okresie. Wśród imigrantów na pobyt czasowy dominowali cudzoziemcy. W 2013 roku stanowili oni 92\% wszystkich imigrantów ${ }^{19}$.

Imigranci czasowi to przede wszystkim obywatele byłego ZSRR, głównie Ukraińcy, Białorusini, Rosjanie. W porównaniu z rokiem 2003 nie nastąpiły

\footnotetext{
${ }^{17}$ Obliczenia własne na podstawie Rocznik Demograficzny 2014, s. 478.

${ }^{18}$ Ibidem.

19 Ibidem.
} 
większe zmiany w strukturze geograficznej imigracji czasowej. Największy wzrost udziału w imigracji czasowej można było zaobserwować wśród obywateli Chin, Turcji i Wietnamu (rysunek 5). W grupie imigrantów czasowych nie występowało zjawisko reemigracji, gdyż była to na ogół typowa imigracja zarobkowa.

Rysunek 5. Imigranci na pobyt czasowy według kraju obywatelstwa w latach 2003 i $2013(\%)$

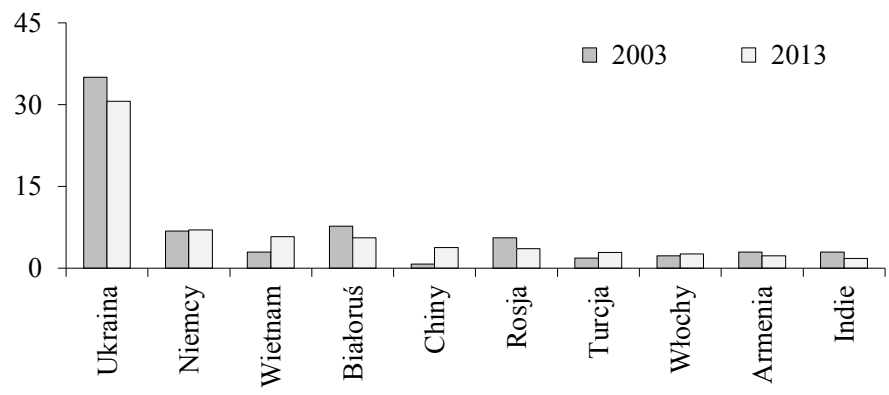

Źródło: opracowanie własne na podstawie Rocznika Demograficznego 2004 i 2014..., s. 455, 498.

Imigranci przyjeżdżający do Polski to głównie osoby młode, w wieku od 20 do 49 lat, przy czym najliczniejsza grupa to osoby między 25.-34. rokiem życia. Dotyczy to jednak w większym stopniu osób przyjeżdżający do Polski na pobyt czasowy (29\% ogółu imigrantów) niż stały (23\%). W porównaniu z 2003 rokiem struktura wieku imigrantów przyjeżdżających do Polski nie uległa większym zmianom. W tamtym okresie dominowała ta sama grupa wiekowa ${ }^{20}$.

Analiza zmian w poziomie wykształcenia imigrantów w okresie 2003-2013 jest utrudniona ze względu na to, że aż dla 66\% imigrantów nie ustalono wykształcenia. Analizując dostępne dane, można zaobserwować duży udział liczbowy osób z wykształceniem licealnym (prawie połowa osób, dla których są dostępne dane) oraz wyższym $(35 \%)^{21}$.

Co trzeci imigrant na miejsce pobytu wybierał województwo mazowieckie. Kolejne województwa zamieszkałe przez imigrantów to dolnośląskie, śląskie i małopolskie. Najmniej imigrantów mieszało w 2013 roku w województwie

\footnotetext{
${ }^{20}$ Rocznik Demograficzny 2004, GUS, Warszawa 2004, s. 435, 455.

${ }^{21}$ Rocznik Demograficzny 2014..., s. 516.
} 
warmińsko-mazurskim i świętokrzyskim. Imigranci wybierali zatem miejsca pobytu najwyżej zurbanizowane i uprzemysłowione. Te miejsca dają szanse na znalezienie pracy. Napływ do małych miast i wsi był znikomy i nie zmienił się od 2003 roku.

W 2013 roku wydano około 40 tysięcy pozwoleń na pracę w Polsce ${ }^{22}$. W porównaniu z 2004 rokiem liczba zezwolenia na pracy wzrosła prawie trzykrotnie. O pozwolenie na pracę w Polsce starali się obywatele 115 krajów, ze wszystkich kontynentów świata ${ }^{23}$. Na polskim rynku pracy dominowali jednak obywatele Ukrainy. W 2013 roku wydano im 8 razy więcej zezwoleń na pracę niż w 2004 roku ${ }^{24}$. Również w przypadku obywateli innych państw liczba wydanych zezwoleń wzrosła wielokrotnie, dotyczy to w szczególności takich państw, jak: Chiny, Indie, Turcja, Uzbekistan, Mołdawia ${ }^{25}$.

W 2013 roku największą grupę zawodową cudzoziemców stanowili pracownicy wykwalifikowani. Jednak ich udział spadł z 34,5\% w 2008 roku do 27,4\% w 2013 roku $^{26}$. Podwoiła się, w porównaniu z 2008 rokiem, liczba pozwoleń wydanych dla pracowników zatrudnionych przy pracach prostych, spadła natomiast liczba zatrudnionej w Polsce zagranicznej kadry kierowniczej (z 27\% na zaledwie 7,7\% w 2013 r.). Może to oznaczać postępującą segmentację na polskim rynku pracy. Rośnie zapotrzebowanie na pracowników w sektorach niecieszących się popularnością wśród pracowników krajowych, ze względu na niskie wynagrodzenie oraz prestiż wykonywanej pracy.

\section{Podsumowanie}

Przeprowadzona analiza procesów migracyjnych w Polsce w ostatnich dziesięciu latach daje podstawy do sformułowania kilku wniosków. Po pierwsze, mimo względnie dobrej sytuacji gospodarczej w naszym kraju nie zmniejszyła się liczba emigrantów z Polski. Po okresie niewielkiego spadku w wyniku światowego

${ }^{22}$ Dane Ministerstwa Pracy i Polityki Społecznej, www.mpips.gov.pl/analizy-i-raporty/cudzoziemcy-pracujacy-w-polsce-statystyki (dostęp lipiec 2014).

${ }^{23}$ Ibidem.

${ }^{24}$ Obliczenia własne na podstawie Rocznika Demograficznego 2007 oraz Rocznika Demograficznego $2013 \ldots$

${ }_{25}$ Dane Ministerstwa Pracy i Polityki Społecznej, www.mpips.gov.pl/analizy-i-raporty...

${ }^{26}$ Ibidem. 
kryzysu gospodarczego liczba osób nieobecnych w Polsce ponownie wzrosła w 2013 roku. Nie zanotowano też wzmożonej fali reemigracji, co wyraźnie obserwowano w krajach UE, które wcześniej przeszły proces transformacji migracyjnej. Polscy obywatele niechętnie wracają do naszego kraju. Problemem jest wysokie bezrobocie połączone z niedopasowaniem o charakterze kompetencyjnym (nadwyżka ludzi z wyższym wykształceniem przy wyraźnym zapotrzebowaniu na wykwalifikowanych robotników).

Po drugie, otwarcie rynków pracy UE wywołało wyraźne zmiany w kierunkach emigracji Polaków. Mieszkańcy naszego kraju wybierają przede wszystkim kraje członkowskie UE. Można mówić o nowych „tradycyjnych” kierunkach emigracji: Wielka Brytania, Irlandia, Norwegia. Polski emigrant poakcesyjny jest młodszy i lepiej wykształcony niż emigrant przedakcesyjny. Wyższe zarobki i dobra opieka społeczna w krajach „starej” UE przyciągają już nie tylko samotnych Polaków, ale coraz częściej całe rodziny.

Pogarszająca się sytuacja demograficzna Polski (zarówno na skutek skali i struktury przyrostu naturalnego, jak i rosnącej liczby młodych emigrantów z Polski) nie była kompensowana wzmożonym napływem imigrantów do Polski. Liczba imigrantów jest nadal relatywnie niewielka, zarówno w liczbach bezwzględnych, jak i w stosunku do populacji całego kraju. Niemniej wykazuje stałą tendencję wzrostową w analizowanym okresie. Może to oznaczać, że Polska powoli staje się krajem atrakcyjnym dla cudzoziemców, dzięki relatywnie dobrej sytuacji gospodarczej i politycznej oraz konsekwentnie wdrażanej od 2007 roku polityce liberalizacji warunków pobytu i dostępu cudzoziemców do polskiego rynku pracy.

Nie zmieniła się w istotny sposób charakterystyka demograficzna i geograficzna statystycznego cudzoziemca przyjeżdżającego do Polski, są to stosunkowo młodzi, dobrze wykształceni i posiadający wysokie kwalifikacje obywatele byłych republik ZSRR (najczęściej Ukrainy).

Na rynku pracy niezmiennie dominują obywatele Ukrainy, ale znacznie wzrosła liczba państw, z których pochodzą imigranci zarobkowi w Polsce. Zmieniła się struktura branżowa pozwoleń w analizowanym okresie. Znacznie spadł odsetek zezwoleń wydawanych w takich sekcjach, jak działalność finansowa i ubezpieczeniowa oraz przetwórstwo przemysłowe, wzrósł natomiast w budownictwie, gospodarstwach domowych oraz rolnictwie. To oznacza, że w Polsce - podobnie jak w innych krajach Europy Zachodniej - zaczyna następować wyraźna segmentacja rynku 
pracy. Segment pierwotny to dobrze opłacane, stwarzające możliwość awansu miejsce pracy. Segment wtórny cechują: niskie płace, złe warunki pracy, niepewność zatrudnienia, brak perspektyw kariery zawodowej, brak reguł i procedur. Rynek wtórny jest $\mathrm{i}$ będzie $\mathrm{w}$ przyszłości $\mathrm{w}$ znacznym stopniu zdominowany przez imigrantów. Pracownicy rodzimi nie są bowiem na ogół zainteresowani pracą w tym sektorze, lecz w sektorze pierwotnym.

Na pytanie, na jakim etapie transformacji migracyjnej jest Polska, można odpowiedzieć, że na etapie wstępnym. Polska jest dopiero na początku przemian migracyjnych. Wydaje się, że w naszym kraju ten proces transformacji potrwa dużo dłużej niż w innych krajach UE i potrzeba jeszcze wielu lat, żeby zerwać ze stereotypem kraju emigracji.

\section{Literatura}

Brzozowski J., Kaczmarczyk P., Konsekwencje migracji poakcesyjnych z polski dla kompetencji zawodowych i kulturowych polskiego społeczeństwa, Komitet Badań nad Migracjami PAN, Warszawa 2014.

European Social Statistics. 2013 Edition, http://epp.eurostat.ec.europa.eu (dostęp lipiec 2013).

Informacje o rozmiarach i kierunkach emigracji z Polski w latach 2004-2013, Raport GUS, październik 2014.

Informacja w sprawie zatrudnienia obywateli polskich w państwach Europejskiego Obszaru Gospodarczego i Szwajcarii oraz obywateli państw EOG w Polsce, maj 2010, www. mpips.gov.pl (dostęp luty 2012).

Kaczmarczyk P., Poakcesyjne migracje Polaków - próba bilansu, „Studia Migracyjne Przegląd Polonijny" 2010, nr 4, Warszawa.

Okólski M., Modernizacyjna rola migracji, „CMR Working Papers” 2011, nr 46.

Okólski M, Polska jako aktor na europejskiej scenie migracyjnej, w: Wspótczesne migracje, dylematy Europy i Polski, Uniwersytet Warszawski, Ośrodek Badań nad Migracjami, Warszawa 2009.

Matkowska M., Obraz polskiego emigranta w świetle danych Narodowego Spisu Powszechnego Ludności i Mieszkań 2011, „Prace i Materiały Wydziału Nauk Ekonomicznych i Zarządzania" nr 35, t. 1, Wydawnictwo Naukowe Uniwersytetu Szczecińskiego, Szczecin 2014.

Metoda szacunku liczby osób przebywajacych czasowo za granica w latach 2002-2008, GUS, Departament Badań Demograficznych, www.stat.gov.pl (dostęp maj 2010). 
Migracje zagraniczne ludności w 2002 roku. Narodowy Spis Powszechny Ludności i Mieszkań 2002, Warszawa 2004, www.stat.gov.pl/gus (dostęp listopad 2013).

Migracje zagraniczne ludności. Narodowy Spis Powszechny Ludności i Mieszkań 2011, Warszawa 2013.

Rocznik Demograficzny GUS, Warszawa (różne roczniki).

Zaspokajanie potrzeb polskiego rynku pracy poprzez migracje, Raport Europejskiej Sieci Migracyjnej, www.emn.gov.pl (dostęp marzec 2012).

\title{
MIGRATION PROCESSES IN THE POST-ACCESSION POLAND
}

\begin{abstract}
Polish accession to the European Union in 2004 resulted in many institutional, economic and social changes. The consequences of membership can also be observed in migration processes. The aim of the paper is to analyse the changes in the Polish migration processes and the attempt to determine what transformation phase we are after ten years of UE membership. These objectives inform the structure of this work; the first part presents the trends in the size and structure of emigration from Poland and their changes after 2004. The second section discusses economic immigration.
\end{abstract}

Translated by Marzena Matkowska

Keywords: international migration, emigration from Poland, immigration to Poland, migration transformations

JEL codes: F22, J11, J61 
